\title{
The effects of four types of anthropogenic disturbances on composition and abundance of terrestrial isopods (Isopoda: Oniscidea)
}

\author{
Mariana J. Magrini'; André V. L. Freitas ${ }^{1} \&$ Marcio Uehara-Prado ${ }^{2,3}$
}

\author{
${ }^{1}$ Departamento de Biologia Animal, Instituto de Biologia, Universidade Estadual de Campinas. Caixa Postal 6109, \\ 13084-971 Campinas, SP, Brazil.E-mail: mamagrini@gmail.com; baku@unicamp.br \\ ${ }^{2}$ Instituto Neotropical: Pesquisa e Conservação. Caixa Postal 19009, 81531-980 Curitiba, PR, Brazil. \\ ${ }^{3}$ Corresponding author. E-mail: muprado@yahoo.com
}

\begin{abstract}
The Brazilian Atlantic Forest is currently reduced to about $12 \%$ of its original range. Among the components that make up its great diversity, there are species with the potential to be bioindicators, which can be very important for conservation-oriented studies. This study compares the species composition, abundance and sex ratio of terrestrial isopods in sites that show different anthropogenic disturbance histories and are located within four reserves in the Atlantic Forest of southwestern Brazil. Our study explores these crustaceans as indicators of anthropogenic disturbance. The influence of one of the following factors was explored in each protected area: 1 ) history of vegetation harvesting, 2) trail management, 3) Eucalyptus planting, and 4) edge effect. A total of 2,217 individuals of six species (Atlantoscia sp., Benthana werneri Lemos de Castro, 1958, Pseudodiploexochus tabularis (Barnard, 1932), Pudeoniscus obscures Lemos de Castro, 1973, Styloniscus spinosus (Patience, 1907), and Trichorhina sp.) were captured in pitfall traps. The composition of isopod species was different between most of the contrasting sites within reserves, and was similar among the less disturbed sites of different reserves. The total number of isopod individuals and the sex ratio were not different between the contrasting sites within most of the reserves and only the sex ratio of Atlantoscia sp. differed between contrasting sites of one protected area. Upon an individual analysis of each species, S. spinosus (an exotic species) was most abundant in more disturbed sites. The distributions of $B$. werneri and Atlantoscia sp. over time were relatively synchronous, except where S. spinosus was abundant. Our results also indicate that the exotic species $S$. spinosus may benefit from the vegetation mosaic produced by disturbance, so differences in abundance of this species may be useful for bioindication. A change in the spatial and temporal structure of Oniscidea communities caused by anthropogenic disturbance may have a cascade effect on ecological cycles because terrestrial isopods play a fundamental role in nutrient cycling.
\end{abstract}

KEY WORDS. Atlantic Forest; bioindicator; conservation.

Among the different types of anthropogenic impacts, habitat loss and fragmentation, and the introduction of exotic species are among the greatest threats to biodiversity (DAviEs et al. 2001, Hong \& Lee 2006). The Brazilian Atlantic Forest, which originally occupied over one million square kilometers of the country's territory, is now reduced to about $12 \%$ of its original range (Ribeiro et al. 2009). That percentage represents both relatively well-preserved and secondary forests, many of which are spread out into isolated and dispersed remnants within a predominantly agricultural or urbanized landscape. The Atlantic Forest biome has had a long history of replacement by plantations and pastures and logging sites over more than two centuries of destruction (FUNDAÇão SOS MatA ATLÂNTICA \& INPE 2001, Ribeiro et al. 2009). Despite intense deforestation and fragmentation, the Atlantic Forest is still extremely biodiverse and, due to the enormous number of endemic species and high rate of habitat destruction therein, it is considered a biodiversity hotspot for conservation priorities (Myers et al. 2000).
Terrestrial invertebrates are important for conservationoriented studies because they are easy to sample and maintain in collections at low costs; because they are also highly sensitive to environment change (KREMEN et al. 1993) they are especially suitable as bioindicators. Terrestrial invertebrates are also extremely abundant: estimates in the Brazilian Amazon suggest that over one billion invertebrates, most of which are edaphic arthropods, are present in one hectare of forest (WILsON 1987). Invertebrates have been used to assess restoration success at mines (ANDERSEN 1993, SimMonds et al. 1994), riparian woodland (Williams 1993), rainforests (NaKamura et al. 2003), and temperate forests (WilletT 2001). In their review of the ecosystem services that are affected by invertebrate activities, LAVELLE et al. (2006) highlight the contribution of the soil biota to water supply, nutrient cycling, soil formation, primary production, flood and erosion control, and climate regulation. Despite many decades of intensive research and the practical consequences of these findings for sustainable management of 
soils, invertebrates are still poorly acknowledged as mediators of soil function and as providers of ecosystem services (LAVELLE et al. 2006).

Within the huge diversity of arthropods, the terrestrial isopods (Isopoda: Oniscidea) are conspicuous components of the soil macrofauna, feeding on decomposing organic matter such as forest litter, rotten wood, fungi and bacteria (SUTTON 1980). They also contribute to the activity of decomposer microorganisms by grazing on dead organic matter or by dispersing bacterial propagules and fungal spores in their feces. In addition, they have an important role in physically removing organic matter from the surface and taking it deeper into the soil (see Hassall et al. 1987, Zimmer 2002b). Given that isopod abundance, species richness, and composition affect the decomposition process (ZiMMER \& TOPP 1999, ZiMMER 2002a, ZiMMER et al. 2002), studies on the effect of anthropogenic disturbances on this group are especially important.

Recent studies have reported differences in the composition and structure of terrestrial isopod communities subjected to different kinds of disturbance and a female-skewed sex ratio in populations from disturbed areas (PAOLETTI \& CANTARINO 2002, Hassall et al. 2006, Moss \& Hassall 2006, Vilisics et al. 2007). Despite their potential as biological indicators, however, only few reports to date has addressed the responses of these crustaceans to anthropogenic disturbance in the Neotropics (e.g. ALMERÃo et al. 2006). The purpose of this study was to compare the composition, abundance and sex ratio of terrestrial isopods in Atlantic Forest areas with different anthropogenic disturbance histories in an attempt to explore their responses as biological indicators of forest disturbance.

\section{MATERIAL AND METHODS}

The study was conducted at the following four Atlantic Forest protected areas in the Serra do Mar mountain range in the state of São Paulo, Brazil: the Boracéia Biological Station located within the property of the São Paulo state's sanitation utility company (SABESP); the Paranapiacaba Biological Reserve; the Parque das Neblinas, a private Natural Heritage Reserve; and the Santa Virgínia nucleus, within the Serra do Mar state park (Fig. 1).

All of the protected areas in this study were once covered by Ombrophilous Dense Forest and they all have a history of anthropogenic disturbance (Tab. I). They are located in a region where the predominant soils are Red-Yellow Argisol (clay-rich soil) and Haplic Cambisol at altitudes ranging from approximately 700-1100 m (IBGE 2005). The predominant climate in the region is humid, without a well-defined dry season, and in the Cwa classification according to KöEppen (1948). In the period from 1977 to 1986, the highest mean maximum temperature was $30.8^{\circ} \mathrm{C}$ (in February) and the lowest mean minimum temperature was $13.4^{\circ} \mathrm{C}$ (in July) (Nascimento \& Pereira 1988). Annual rainfall ranges from ca. 1860 to ca. $4400 \mathrm{~mm}$ in the re-

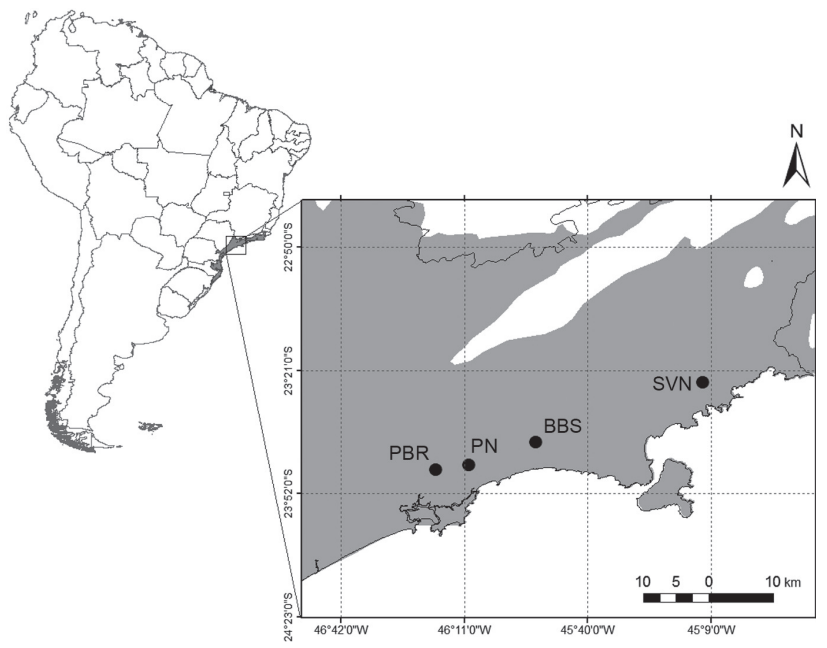

Figure 1. Location of the four protected areas in the Serra do Mar vegetation complex. The Serra do Mar ecoregion is indicated in gray. (BBS) Boracéia Biological Station, (PBR) Paranapiacaba Biological Reserve, (PN) Parque das Neblinas, (SVN) Santa Virgínia nucleus.

serves and the lowest mean monthly precipitation is $48 \mathrm{~mm}$ (SIGRH 2008). The weather changes frequently in all of the areas and fog is a common occurrence.

Sampling was conducted with the aim of comparing sites with different levels of anthropogenic disturbance within each protected area. The types of anthropogenic disturbance were distinct at each protected area, namely: 1) history of cutting/ logging, 2) trail management, 3) eucalyptus planting, and 4) edge effect. At each protected area, less-disturbed reference sites were compared with other, more disturbed sites (Tab. I).

Twelve sampling units were set up at each protected area and separated into six transects in each differently disturbed site. These transects were at least $120 \mathrm{~m}$ apart (median $=150$ $\mathrm{m})$. Each sampling unit comprised five pitfall traps arranged in a line and placed approximately two meters apart from each other. The pitfall traps were made of $500 \mathrm{ml}$ plastic containers that were $8.5 \mathrm{~cm}$ in diameter, buried so the opening would be flush with the ground and protected from rain and falling leaves by a styrofoam cover. A mixture of $69.9 \%$ water, $30.0 \%$ propylene glycol, $0.1 \%$ formaldehyde and some drops of detergent (to break the surface tension and facilitate arthropod collection) was used as preserving liquid. The traps were left open in the field for six days per month. Sampling at the Santa Virgínia nucleus was done from November 2004 to May 2005. Likewise, the Boracéia Biological Station and the Parque das Neblinas were sampled from November 2005 to May 2006, and collections at the Paranapiacaba Biological Reserve took place from November 2006 to May 2007.

The collected isopods were sorted on white trays and preserved in $70 \%$ ethanol. The mancas (individuals with six 
Table I. Main characteristics of the four studied protected areas in the Serra do Mar vegetation complex. * All located in a continuum along the Serra do Mar vegetation complex; see figure 1.

\begin{tabular}{|c|c|c|c|c|c|c|}
\hline \multirow{2}{*}{ Protected area (established in) } & \multirow{2}{*}{$\begin{array}{l}\text { Geographic } \\
\text { coordinates }\end{array}$} & \multirow{2}{*}{$\begin{array}{c}\text { Legal } \\
\text { area (ha)* }\end{array}$} & \multirow{2}{*}{ Vegetation } & \multicolumn{2}{|c|}{ Disturbance condition } & \multirow{2}{*}{ Disturbance history } \\
\hline & & & & More disturbed & Less disturbed & \\
\hline $\begin{array}{l}\text { Boracéia Biological Station } \\
\text { (1954) }\end{array}$ & $\begin{array}{l}23^{\circ} 39^{\prime} \mathrm{S} \\
45^{\circ} 53^{\prime} \mathrm{W}\end{array}$ & 100 & Mature forest & Managed trails & $\begin{array}{l}\text { Unmanaged } \\
\text { trails }\end{array}$ & $\begin{array}{l}\text { A disturbed area where the trails are } \\
\text { periodically used and managed (vegetation } \\
\text { trimming) by employees of the water } \\
\text { company. An undisturbed area occasionally } \\
\text { used by researchers but mostly unused. }\end{array}$ \\
\hline $\begin{array}{l}\text { Paranapiacaba Biological } \\
\text { Reserve (1909) }\end{array}$ & $\begin{array}{l}23^{\circ} 46^{\prime} \mathrm{S} \\
46^{\circ} 18^{\prime} \mathrm{W}\end{array}$ & 336 & Secondary forest & Forest edge & Forest interior & $\begin{array}{l}\text { The reserve is surrounded by a highway, a } \\
\text { railroad track and power transmission lines. } \\
\text { The interior mainly comprises secondary } \\
\text { forest at different stages of regeneration. }\end{array}$ \\
\hline Parque das Neblinas (2004) & $\begin{array}{l}23^{\circ} 47^{\prime} \mathrm{S} \\
46^{\circ} 11^{\prime} \mathrm{W}\end{array}$ & 2788 & $\begin{array}{l}\text { Secondary forest } \mathrm{x} \\
\text { Eucalyptus saligna } \\
\text { plantation }\end{array}$ & $\begin{array}{l}\text { Eucalyptus } \\
\text { saligna } \\
\text { plantation }\end{array}$ & Native forest & $\begin{array}{l}\text { This disturbed area was clear-cut then } \\
\text { replaced with Eucalyptus from } 1939 \\
\text { onward. Secondary forest with trails used } \\
\text { daily by employees of a hydroelectric plant } \\
\text { and, occasionally, by researchers. }\end{array}$ \\
\hline Santa Virgínia nucleus (1989) & $\begin{array}{l}23^{\circ} 17^{\prime} \mathrm{S} \\
45^{\circ} 03^{\prime} \mathrm{W}\end{array}$ & 9000 & $\begin{array}{l}\text { Secondary } x \\
\text { mature forest }\end{array}$ & $\begin{array}{l}\text { History of } \\
\text { slashing and } \\
\text { burning }\end{array}$ & $\begin{array}{l}\text { History of } \\
\text { selective } \\
\text { logging }\end{array}$ & $\begin{array}{l}\text { A disturbed area deforested by slashing } \\
\text { and burning in the } 1960 \text { s. This area is } \\
\text { currently a mosaic of mature forest areas } \\
\text { interspersed with forest at different stages } \\
\text { of regeneration, pastures, and man-made } \\
\text { Eucalyptus stands. (see TABARELL \& } \\
\text { MANTOVANI 1999). An undisturbed area } \\
\text { comprising relatively well-preserved } \\
\text { mature forest with some remnants of } \\
\text { primary forest where selective logging took } \\
\text { place until } 1970 \text { (J.P. Villani, pers. comm.). }\end{array}$ \\
\hline
\end{tabular}

pairs of pereopod) were separated from juveniles and adults, which were then sexed (following Araujo et al. 2004). The collected material was deposited at the Museu de Zoologia, Universidade Estadual de Campinas.

To verify the relationship of species composition among contrasting sites and areas, non-metric multidimensional scaling (NMDS) was performed on the resemblance matrix of BrayCurtis distances after a $\log (\mathrm{x}+1)$ transformation on the original data. Differences in the abundance between the contrasting sites within each protected area were analyzed by permutation t-tests for pooled isopods and for the most abundant species. Chi-square tests were applied to detect deviations in sex ratio (males:females) from the expected proportion of $1: 1$ and to detect any sex ratio variation between the contrasting sites. Only species with $n>5$ were analyzed.

\section{RESULTS}

A total of 2,217 individuals were collected, distributed among six species of five different terrestrial isopod families: Atlantoscia sp. ("Philosciidae"), Benthana werneri Lemos de Castro, 1958 ("Philosciidae"), Styloniscus spinosus (Patience, 1907) (Styloniscidae), Trichorhina sp. ("Platyarthridae"), Pudeoniscus obscurus Lemos de Castro, 1973 (Pudeoniscidae), and Pseudodiploexochus tabularis (Barnard, 1932) (Armadillidae). Both S. spinosus and P. tabularis are introduced species and native to Hawaii and South Africa, respectively (Leistikow \& WÄGeLE
1999, Schmalfuss 2003). With the exception of Styloniscidae, which belongs to section Synocheta, the remaining species are from section Crinocheta, which are adapted to habitats that are rather dry compared to the habitats of the other terrestrial Isopoda (ScHмidT 2008). Although there are some historical and biogeographical records for isopod species in the American continent, data on their native distribution remains scarce. The existing data on the occurrence and native distribution of the species found in this study are available in MAGRINI et al. (2010).

The species composition of the contrasting sites was clearly separated from each other in NMDS ordination space except for the Boracéia Biological Station, where it was indistinguishable (Fig. 2). The less disturbed sites of three reserves are clustered in the ordination space along with both sites of the Boracéia Biological Station. The main differences among the reserves as well as between the contrasting sites into each protected area are described below.

A range of 1-4 species and 3-228 individuals were collected at each sampling unit for a mean value of $46.2(\mathrm{SD} \pm 57.6$ ) individuals per sampling unit. The protected area with the highest number of individuals was the Boracéia Biological Station, which yielded 1,224 individuals from three species, followed by the Parque das Neblinas (466), the Paranapiacaba Biological Reserve (330) and the Santa Virgínia nucleus (197), all of which yielded four species (Tab. II). Atlantoscia sp. was the dominant species at three of the protected areas and comprised as high as $94.4 \%$ of the captured individuals at the Boracéia Biological 


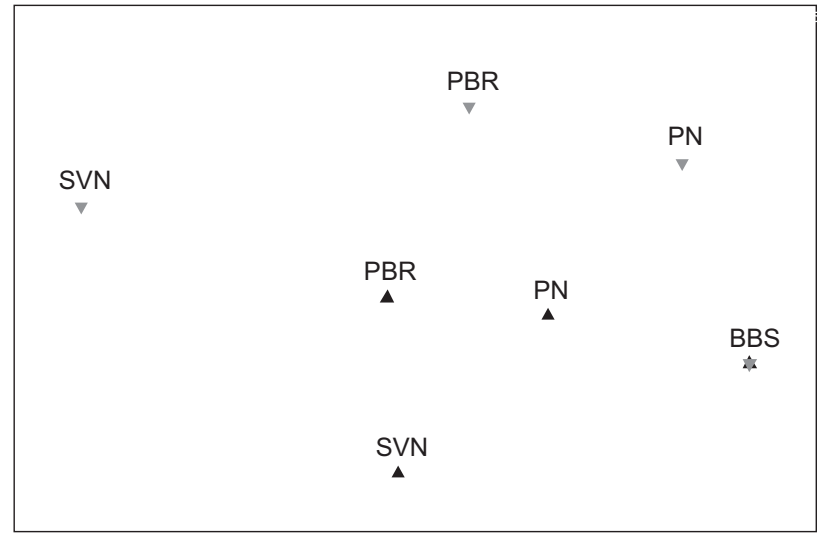

Figure 2. NMDS ordination of isopod species composition in more disturbed (grey inverted triangles) and less disturbed (black triangles) sites in each protected area. (BBS) Boracéia Biological Station, (PBR) Paranapiacaba Biological Reserve, (PN) Parque das Neblinas, (SVN) Santa Virgínia nucleus.

Station (Tab. II). At the Santa Virgínia nucleus, this species was the second most abundant and surpassed only by the exotic species $S$. spinosus, which comprised $41.6 \%$ of the individuals captured in that area. Atlantoscia sp. and B. werneri, both "Philosciidae", appeared jointly at all protected areas. In total, P. obscurus, P. tabularis, and Trichorhina sp. showed a relative abundance of $0.5 \%$ at the Santa Virgínia nucleus and less than $4 \%$ in the other protected areas.
The mean number of isopod individuals was not different among the contrasting sites of three protected areas with the exception of the Boracéia Biological Station, where the more disturbed site (148.2 \pm 77.1$)$ showed 2.7 more Isopoda individuals than the less disturbed one $(55.8 \pm 56.3)$ (Fig. 3$)$. When the species were analyzed individually, only the exotic species $S$. spinosus showed a significant difference, being much more abun-

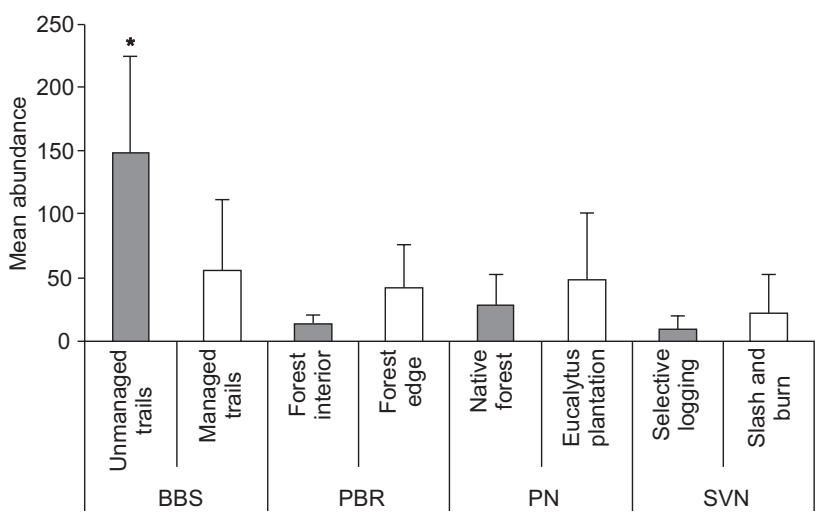

Figure 3. Mean abundance of isopods in the contrasting sites of the four protected areas sampled. Gray and white bars indicate less and more disturbed sites in the same protected area, respectively. ${ }^{*}=$ permutation t-test, $\mathrm{p}<0.05$. (BBS) Boracéia Biological Station, (PBR) Paranapiacaba Biological Reserve, (PN) Parque das Neblinas, (SVN) Santa Virgínia nucleus.

Table II. Abundance of Oniscidea (Isopoda) at four sites of varying disturbance within Atlantic Forest protected areas in the Serra do Mar mountains, state of São Paulo.

\begin{tabular}{|c|c|c|c|c|c|c|c|c|}
\hline \multirow[b]{2}{*}{ Species } & \multicolumn{2}{|c|}{ Boracéia Biological Station } & \multicolumn{2}{|c|}{ Paranapiacaba Biological Reserve } & \multicolumn{2}{|c|}{ Parque das Neblinas } & \multicolumn{2}{|c|}{ Santa Virgínia nucleus } \\
\hline & $\begin{array}{l}\text { Managed } \\
\text { trails }\end{array}$ & $\begin{array}{l}\text { Unmanaged } \\
\text { trails }\end{array}$ & Forest edge & Forest interior & $\begin{array}{l}\text { Eucalyptus } \\
\text { plantation }\end{array}$ & $\begin{array}{l}\text { Native } \\
\text { forest }\end{array}$ & $\begin{array}{c}\text { Slash and } \\
\text { burn }\end{array}$ & $\begin{array}{l}\text { Selective } \\
\text { logging }\end{array}$ \\
\hline \multicolumn{9}{|l|}{ Armadillidae } \\
\hline P. tabularis* & & & 3 & 1 & & & & \\
\hline \multicolumn{9}{|l|}{ Philosciidae } \\
\hline Atlantoscia sp. & 308 & 836 & 217 & 62 & 259 & 148 & 42 & 31 \\
\hline B. werneri & 19 & 49 & 24 & 16 & 28 & 26 & 14 & 27 \\
\hline \multicolumn{9}{|l|}{ Platyarthridae } \\
\hline Trichorhina sp. & 8 & 4 & & & & & & 1 \\
\hline \multicolumn{9}{|l|}{ Pudeoniscidae } \\
\hline P. obscurus & & & & & 4 & & & \\
\hline \multicolumn{9}{|l|}{ Styloniscidae } \\
\hline S. spinosus* & & & 7 & & 1 & & 80 & 2 \\
\hline Total & 335 & 889 & 251 & 79 & 292 & 174 & 136 & 61 \\
\hline
\end{tabular}

* Exotic species. 
dant in the more disturbed (80 individuals) than in the less disturbed site (two individuals) at the Santa Virgínia nucleus (permutation t-test, $\mathrm{p}=0.004$ ). This species was also present in the more disturbed sites of the Paranapiacaba Biological Reserve and the Parque das Neblinas, although at low abundance (Tab. II).

February was the month with the greatest isopod abundance at all protected areas, yielding more than 20\% of the total samples at each area (Tab. III). The three most abundant species (Atlantoscia sp., B. werneri, and S. spinosus) were present during most of the sampled period. Atlantoscia sp. and B. werneri increased in abundance from November to February. Both species reached their peak abundance in February at all, except in the Santa Virgínia nucleus, where they peaked in January, while the exotic species $S$. spinosus peaked in February (Tab. III).

Total sex ratio was skewed toward females in most samples, although significant differences were found in only four cases: Benthana werneri $\left(\chi^{2}=4.90, \mathrm{p}=0.027\right)$ and $S$. spinosus $\left(\chi^{2}=18.78, \mathrm{p}<0.001\right)$ in the Santa Virgínia nucleus and Atlantoscia sp. in the Boracéia Biological Station $\left(\chi^{2}=34.49\right.$, $\mathrm{p}<0.001)$ and in the Parque das Neblinas $\left(\chi^{2}=7.48, \mathrm{p}=0.006\right)$. Regarding the contrasting sites within each protected area, no difference in male to female ratio was detected for any of the analyzed species except Atlantoscia sp. in the Boracéia Biological Station $\left(\chi^{2}=0.098, p=0.003 ; \mathrm{DF}=1\right)$, where the male to female ratio found in unmanaged trails $(0.75)$ was 1.6 times higher than that found in managed trails (0.48).

\section{DISCUSSION}

Some studies have emphasized that terrestrial isopods respond predictably to environmental stress and that habitat disturbance impacts assemblage composition, leading to significant changes in the abundance and species richness (e.g.
Kalisz \& Powell 2004, Pitzalis et al. 2005). In this study, we found that quantitative species composition of the contrasting sites is clearly different for three out of four of the reserves. Additionally, we found that the abundance of an exotic species is positively affected by disturbance in one of the studied reserves and that the increase in its abundance may affect temporal distribution of other native species.

The low number of species found in all areas can be partially explained by the collection method employed. Pitfall traps favor capturing mobile species that live in the leaf-litter layer, whereas small-sized species with low mobility (P. tabularis, for instance) and those that are endogean and live under logs and rocks will probably be absent or underestimated in the sampling (Trichorhina and Styloniscus, for instance). Although the limitations of pitfall traps should be taken into account when interpreting results (upon which the biology of each group should be considered), these traps are a valid methodological tool that is one of the principal methods for invertebrate sampling (New 1999). Therefore, our sampling system enabled comparisons between the contrasting sites of each protected area, which validates our results for comparative purposes.

Even with few species in each protected area, the species composition was distinct between contrasting sites of three reserves, reinforcing the usefulness of this parameter in biological indication studies (BARLow et al. 2007, BASSET et al. 2008, Uehara-Prado et al. 2009). The only exception was in the Boracéia Biological Station, where disturbance was inferred by trail management, which seems to be irrelevant to isopods. The proximity of both contrasting sites of the Boraceia reserve (the best preserved reserve in this study) to the less disturbed sites of the other reserves in the ordination space indicates that disturbance may generate consistent composition patterns for terrestrial isopods.

Table III. Abundance of Atlantoscia sp., B. werneri, and S. spinosus over time at the four protected areas.

\begin{tabular}{|c|c|c|c|c|c|c|c|c|}
\hline Protected area (sampling years) & Species & Nov & Dec & Jan & Feb & Mar & Apr & May \\
\hline \multirow[t]{3}{*}{ Boracéia Biological Station (2005-2006) } & Atlantoscia sp. & 160 & 188 & 213 & 283 & 157 & 62 & 81 \\
\hline & Benthana werneri & 9 & 7 & 16 & 22 & 6 & 2 & 6 \\
\hline & Styloniscus spinosus & 0 & 0 & 0 & 0 & 0 & 0 & 0 \\
\hline \multirow[t]{3}{*}{ Paranapiacaba Biological Reserve (2006-2007) } & Atlantoscia sp. & 20 & 37 & 37 & 64 & 51 & 40 & 30 \\
\hline & Benthana werneri & 0 & 2 & 4 & 10 & 9 & 8 & 7 \\
\hline & Styloniscus spinosus & 1 & 0 & 0 & 4 & 0 & 1 & 1 \\
\hline \multirow[t]{3}{*}{ Parque das Neblinas (2005-2006) } & Atlantoscia sp. & 37 & 77 & 74 & 92 & 57 & 37 & 33 \\
\hline & Benthana werneri & 8 & 7 & 12 & 15 & 9 & 3 & 0 \\
\hline & Styloniscus spinosus & 0 & 0 & 0 & 0 & 0 & 1 & 0 \\
\hline \multirow[t]{3}{*}{ Santa Virginia nucleus (2004-2005) } & Atlantoscia sp. & 15 & 10 & 17 & 13 & 3 & 10 & 5 \\
\hline & Benthana werneri & 3 & 8 & 10 & 3 & 7 & 8 & 2 \\
\hline & Styloniscus spinosus & 16 & 14 & 4 & 26 & 2 & 5 & 15 \\
\hline
\end{tabular}


The most abundant species in this study were Atlantoscia sp. and B. werneri, two genera occurring jointly in Atlantic Forest sites (van Name 1940). Atlantoscia was already reported as dominant in different phytogeographic regions of Brazil, including the Atlantic Forest (Lopes et al. 2005, Almerão et al. 2006). In Almerão et al. (2006), Atlantoscia floridana was highly abundant and was pointed out as a generalist species in terms of habitat, appearing in different landscapes and frequently in large numbers. Besides occurring together spatially, these species also showed a joint temporal distribution with a peak abundance in February, except in the Santa Virgínia nucleus. In this area, the introduced species $S$. spinosus was the most abundant species, with disjunct temporal distribution in relation to the aforementioned species and a peak abundance in February. Establishment and invasion success depend on how the characteristics of a new species relate to the native community (Strauss et al. 2006). According to Strauss et al. (2006), invasion success can be explained by Darwin's naturalization hypothesis, according to which new genera become naturalized more successfully at new sites where there are no native congeners. This may be due to a lower overlap in resource use and, consequently, less competition. Furthermore, exotic species that are phylogenetically close to native species may be more efficiently controlled by natural enemies, which would diminish their establishment success (KeANE \& CRAWLEY 2002). Although the seasonal distribution of terrestrial arthropod species is influenced by variations in climate factors such as temperature and rainfall (e.g. ZiMMER 2004), both hypotheses could explain the establishment and invasion success of $S$. spinosus, a species from a different clade than those which are native.

Regarding the number of individuals of each species, Atlantoscia sp. and B. werneri did not present a significant difference in mean abundance between the contrasting sites of the protected areas, indicating that they are generalist species in terms of habitat and can occur in environments subjected to different types of anthropogenic disturbance. Styloniscus spinosus, on the other hand, was highly abundant in more disturbed sites at the Santa Virgínia nucleus as compared to the sites subjected to selective logging. Although no significant differences were found between the two sites considering the abundance of native species, the disturbance found in the current habitat was enough to favor this introduced species. A survey conducted in Australia shows that the modification of the original vegetation with the introduction of exotic plant species has had impacts on the abundance and composition of litter invertebrate fauna (Lindsay \& French 2006). Of the two isopod species found in that study, one was favored by the invasion, as were species of millipedes, amphipods, earthworms, and pseudoscorpions (LindSAY \& FRENCH 2006). In another study that examined the pattern of occurrence of exotic isopods in the USA, two species of exotic terrestrial isopods were absent in undisturbed forest areas but present in disturbed areas such as roadsides (KAlisz \& Powell 2004). We should note that in our study, S. spinosus occurred exclusively in the more disturbed sites of two other protected areas, but the abundance was not sufficient for statistical analysis. Besides $S$. spinosus, exotic species of landhoppers (Amphipoda, Talitridae) and earthworms (Oligochaeta, Lumbricina) sampled in the Santa Virginia nucleus were also more abundant at the more disturbed sites (Matavell et al. 2009, Fernandes et al. 2010), suggesting that biological invasion may be a good indicator of the conservation of Atlantic Forest sites (Uehara-Prado et al. 2009).

Although sex ratio was skewed toward females in most samples, our general results did not reveal a striking influence of anthropogenic disturbance on the observed sex ratio deviations. The only exception was Atlantoscia sp. at the Boracéia Biological Station, which had a higher female proportion in the more disturbed site. In their work on the terrestrial isopod Trachelipus rathkei (Brandt, 1833), PaOletti \& Cantarino (2002) showed that the population from a rural habitat under strong anthropogenic disturbance presented a significantly higher prevalence of females compared to a less disturbed habitat. The authors suggest that in intensely disturbed surroundings, populations that are able to adjust their sex ratio to increase their intrinsic growth rate may be favored by natural selection; thus, female prevalence in the samples could be an indication that a population has undergone intense pressure from disturbance. However, it has already been shown that the sex ratio of some natural populations of terrestrial isopods varies considerably, even within a single species (e.g. Dangerfield \& Hassall 1994).

The overall predominance of females found for most species in this study may be a result of a Wolbachia infection. Wolbachia is an intracellular bacterium that infects many arthropods and affects their reproduction with such effects as cytoplasmic incompatibility, parthenogenesis, and feminization (WeRREN 1997). Feminization enables the parasite to transmit its genes to the next generation through the host's oocytes, thereby resulting in a female-skewed sex ratio (WERREN 1997). The order Isopoda is frequently infected by Wolbachia, with an estimated infection rate of 35\% (Bouchon et al. 1998). Because we did not investigate the presence of Wolbachia in our samples, further experiments are needed to clarify the role of this parasite in our results.

Many studies have shown that, either directly or indirectly, anthropogenic disturbance has a clear influence on invertebrate richness, abundance, and/or composition, although few studies on terrestrial isopods have been published on this matter (e.g. King et al. 1998, Hassall et al. 2006, Moss \& Hassall 2006, Vilisics et al. 2007). The data presented in this work show that the exotic species $S$. spinosus might benefit from the vegetation mosaic produced by slashing and burning. Therefore, besides species composition, the abundance of $S$. spinosus may be useful for bioindication, making this a potentially helpful species for assessing and monitoring anthropogenic disturbance in the Atlantic Forest.

The modification of Oniscidea community structure by habitat disturbance, introduction of exotic species, and skewed 
sex ratios, among other factors, could have a cascade effect on ecological cycles because, as components of the decomposer macrofauna, terrestrial isopods play a fundamental role in important processes like nutrient cycling. The Neotropical region still lacks basic studies such as inventories, identification guides, and studies on the natural history and population biology of Oniscidea species. Therefore, we suggest that studies following a more complex sampling protocol be conducted to fill in the gaps and advance our knowledge of the applicability of these animals as bioindicators.

\section{ACKNOWLEDGMENTS}

The authors are grateful to all students who participated in the project "Arthropods as biological indicators of anthropogenic disturbance in the Atlantic Forest", especially Huang S.F., J.O. Fernandes and C. Matavelli, for their assistance with field and laboratory work. We thank P.B. Araujo of the Departamento de Zoologia, Instituto de Biociências, Universidade Federal do Rio Grande do Sul, for identifying the species studied and J.G.R. Giovanelli for producing the map. Two anonymous reviewers improved earlier versions of the manuscript. The following persons and institutions provided work permits and logistic support that enabled the completion of this work: J.P. Villani and Cotec staff (Instituto Florestal), R. Bianchini and C.J.F. de Oliveira Jr. (Instituto de Botânica), G.R. Dias (Instituto Ecofuturo), H.E.D. Zaher (Museu de Zoologia, USP), H.K. Boscolo and S.A. Saccardo (Ibama). AVLF thanks the FAPESP (grants 00/01484-1 and 04/05269-9) and the CNPq (grant 300282/2008-7). This study was conducted as part of the doctoral thesis in Ecology of M.U.-P. (CNPq 140116-20044) and the undergraduate research project of M.J.M (CNPq/ PIBIC) at the Universidade Estadual de Campinas.

\section{LITERATURE CITED}

Almerão, M.P.; M.S. Mendonça Jr; A.F. Quadros; E. Pedó; L.G.R. Silva \& P.B. Araujo. 2006. Terrestrial isopod diversity in the subtropical Neotropics: Itapuã State Park, southern Brazil. Iheringia, Série Zoologia, 96 (4):473-477. doi: 10.1590/ S0073-47212006000400012.

Andersen, A.N. 1993. Ants as Indicators of Restoration Success at a Uranium Mine in Tropical Australia. Restoration Ecology 1 (3): 156-167. doi: 10.1111/j.1526-100X.1993.tb00022.x.

Araujo, P.B.; M.M. Augusto \& G. Bond-Buckup. 2004. Postmarsupial development of Atlantoscia floridana (van Name, 1940) (Crustacea, Isopoda, Oniscidea): the manca stages. Journal of Natural History 38 (8): 951-965. doi: 10.1080/002229303 1000068428.

Barlow, J.; T.A. Gardner; I.S. Araujo; T.C. Avila-Pires; A.B. Bonaldo; J.E. Costa; M.C. Esposito; L.V. Ferreira; J. Hawes; M.M. Hernandez; M.S. Hoogmoed; R.N. Leite; N.F. Lo-Man-Hung; J.R. Malcolm; M.B. Martins; L.A.M. Mestre; R. Miranda-Santos; A.L. NunesGutjahr; W.L. Overal; L. Parry; S.L. Peters; M.A. Ribeiro-Junior;
M.N.F. Da Silva; C.S. MotTa \& C.A. Peres. 2007. Quantifying the biodiversity value of tropical primary, secondary, and plantation forests. Proceedings of the National Academy of Sciences of the United States of America 104 (47): 1855518560. doi: 10.1073/pnas.0703333104.

Basset, Y.; O. Missa; A. Alonso; S.E. Miller; G. Curletti; M. De Meyer; C. Eardley;,O.T. Lewis; M.W. Mansell; V. Novotny \& T. WAGNER. 2008. Choice of metrics for studying arthropod responses to habitat disturbance: one example from Gabon. Insect Conservation and Diversity 1 (1): 55-66. doi: 10.1111/j.1752-4598.2007.00011.x.

Bouchon, D.; T. Rigaud \& P. Juchault. 1998. Evidence for widespread Wolbachia infection in isopod crustaceans: molecular identification and host feminization. Proceedings of the Royal Society of London 265 (1401): 1081-1090.

Dangerfield, J.M. \& M. Hassall. 1994. Shelter site use and secondary sex ratios in the woodlice Armadillidium vulgare and Porcellio scaber (Crustacea: Isopoda). Journal of Zoology 233 (1): 1-7. doi: 10.1111/j.1469-7998.1994.tb05257.x.

Davies, K.F.; C. Gascon \& C.R. Margules. 2001. Habitat fragmentation, p. 81-97. In: M.E. SOUlÉ \& G.H. OrInAS (Eds). Conservation biology. Research priorities for the next decade. Washington, D.C., Island Press, 307p.

Fernandes, J.O.; M. Uehara-Prado \& G.G. Brown. 2010. Minhocas exóticas como indicadoras de perturbação antrópica em áreas de Floresta Atlântica. Acta Zoológica Mexicana (n.s.) 2: 211-217.

Fundação SOS Mata Atlântica \& INPE. 2001. Atlas dos remanescentes florestais da Mata Atlântica e ecossistemas associados no período de 1995-2000. São Paulo, Fundação SOS Mata Atlântica, Instituto Nacional de Pesquisas Espaciais, 55p.

Hassall, M.; J.G. Turner \& M.R.W. Rands. 1987. Effects of terrestrial isopods on the decomposition of woodland leaf litter. Oecologia 72 (4): 597-604. doi: 10.1007/BF00378988.

Hassall, M.; D.T. Jones; S. Taiti; Z. Lapiti; S.L. Sutton \& M. MohAmmed. 2006. Biodiversity and abundance of terrestrial isopods along a gradient of disturbance in Sabah, East Malaysa. European Journal of Soil Biology 42 (1): S197S207. doi:10.1016/j.ejsobi.2006.07.002.

Hong, S.K. \& J.A. LeE. 2006. Global environmental changes in terrestrial ecosystems. International issues and strategic solutions: introduction. Ecological Research 21 (6): 783787. doi: 10.1007/s11284-006-0032-x.

IBGE. 2005. Mapas Interativos. Available online at: http:// mapas.ibge.gov.br [Accessed: 15.V.2008].

Kalisz, P.J. \& J.E. Powell. 2004. Exotic isopods (Crustacea: Isopoda) in disturbed and undisturbed forest soils on the Cumberland Plateau of Kentucky, USA. Natural Areas Journal 24 (1): 54-56.

Keane, R.M. \& M.J. Crawley. 2002. Exotic plant invasions and the enemy release hypothesis. Trends in Ecology \& Evolution 17 (4): 164-170. doi: 10.1016/S0169-5347(02)02499-0. 
King, J.R.; A.N Andersen \& A.D. Cutter. 1998. Ants as bioindicators of habitat disturbance: validation of the functional group model for Australia's humid tropics. Biodiversity and Conservation 7 (12): 1627-1638. doi: 10.1023/A:1008857214743.

KöPpen, W. 1948. Climatología con un estudio de los climas de la tierra. México, Fondo de Cultura Económica, 478p.

Kremen, C.; R.K. Colwell; T.L. Erwin; D.D. Murphy; R.F. Noss \& M.A. SANJAYAN. 1993. Terrestrial arthropod assemblages: their use in conservation planning. Conservation Biology 7 (4): 796-808.

Lavelle, P.; T. Decaëns; M. Aubert; S. Barot; M. Blouin; F. Bureau; P. Margerie; P. Mora \& J.-P. Rossi. 2006. Soil invertebrates and ecosystem services. European Journal of Soil Biology 42 (1): S3-S15. doi:10.1016/j.ejsobi.2006.10.002.

Leistikow, A \& J.W. Wägele. 1999. Checklist of the terrestrial isopods of the new world (Crustacea, Isopoda, Oniscidea). Revista Brasileira de Zoologia 16 (1): 1-72. doi: 10.1590/ S0101-81751999000100001.

Lindsay, E.A. \& K. French. 2006. The impact of the weed Chrysanthemoides monilifera ssp. rotundata on coastal leaf litter invertebrates. Biological Invasions 8 (2): 177-192. doi: 10.1007/s10530-004-5856-0.

Lopes, E.R.C.; M.S. Mendonça Jr; G. Bond-Buckup \& P.B. Araujo. 2005. Oniscidea diversity across three environments in an altitudinal gradient in northeastern Rio Grande do Sul, Brazil. European Journal of Soil Biology 41 (3-4): 99-107. doi: 10.1016/j.ejsobi.2005.11.002.

Magrini, M.J.; P.B. Araujo \& M. Uehara-Prado. 2010. Crustacea, Isopoda, Oniscidea Latreille, 1802: New continent record and distribution extension in Brazil. Check List 6 (2): 217 219.

Matavelli, C.; M. Uehara-Prado; F.P.P. Leite \& A.V.L. Freitas. 2009. Some aspects of the population ecology of the exotic amphipod, Talitroides topitotum, in an Atlantic Forest Reserve in Brazil. Crustaceana (Leiden) 82 (2): 241-251. doi: $10.1163 / 156854008 X 363777$.

Moss, A. \& M. Hassall. 2006. Effects of disturbance on the biodiversity and abundance of isopods in temperate grasslands. European Journal of Soil Biology 42 (1): 254268. doi: 10.1016/j.ejsobi.2006.07.013.

Myers N.; R.A. Mittermeier; C.G. Mittermeier; G.A.B. Fonseca \& J. KENT. 2000. Biodiversity hotspots for conservation priorities. Nature 403: 853-858.

Nakamura A.; H. Proctor \& C.P. Catterall. 2003. Using soil and litter arthropods to assess the state of rainforest restoration. Ecological Management and Restoration 4: 20-28. doi: 10.1046/j.1442-8903.4.s.3.x.

Nascimento, C.M. \& M.A.M.G. Pereira. 1988. Atlas climatológico do Estado de São Paulo (1977-1986). Campinas, Fundação Cargill, 93p.

New, T.R. 1999. By-catch, ethics, and pitfall traps. Journal of Insect Conservation 3: 1-3.
Paoletti, M.G. \& C.M. Cantarino. 2002. Sex ratio alterations in terrestrial woodlice populations (Isopoda: Oniscidea) from agroecosystems subjected to different agricultural practices in Italy. Applied Soil Ecology 19 (2): 113-120. doi: 10.1016/ S0929-1393(01)00184-6.

Pitzalis, M.; S. Fattorini; E. Trucchi \& M.A. Bologna. 2005. Comparative analysis of species diversity of Isopoda Oniscidea and Collembola communities in burnt and unburnt habitats in central Italy. Italian Journal of Zoology 72 (2): 127-140. doi: 10.1080/11250000509356663.

Ribeiro, M.C.; J.P. Metzger; A.C. Martensen; F.J. Ponzoni \& M.M. Hirota. 2009. The Brazilian Atlantic Forest: How much is left, and how is the remaining forest distributed? Implications for conservation. Biological Conservation 142 (6): 1141-1153. doi: 10.1016/j.biocon.2009.02.021.

Schmidt, C. 2008. Phylogeny of the terrestrial Isopoda (Oniscidea): a review. Arthropod Systematics \& Phylogeny 66 (2): 191-226.

Schmalfuss, H. 2003. World catalog of terrestrial isopods (Isopoda: Oniscidea). Stuttgarter Beiträge zur Naturkunde, Serie A, 654: 1-341.

SIGRH. 2008. Sistema Integrado de Gerenciamento de Recursos Hídricos de São Paulo. Available online at: http:// www.sigrh.sp.gov [Accessed: 02.VI.2008].

Simmonds, S.J.; J.D. Majer \& O.G. Nichols. 1994. A comparative study of spider (Araneae) communities of rehabilitated bauxite mines and surrounding forest in the southwest of Western Australia. Restoration Ecology 2 (4): 247-260. doi: 10.1111/j.1526-100X.1994.tb00057.x

Strauss, S.Y.; C.O. Webb \& N. Salamim. 2006. Exotic taxa less related to native species are more invasive. Proceedings of the National Academy of Sciences of the United States of America 103 (15): 5841-5845. doi: 10.1073/pnas.0508073103. Sutton, S. L. 1980. Woodlice. Oxford, Pergamon, 144p.

Tabarelli, M. \& W. Mantovani. 1999. A regeneração de uma floresta tropical montana após corte e queima (São Paulo-Brasil). Revista Brasileira de Biologia 59 (2): 239-250. doi: 10.1590/S0034-71081999000200008.

Uehara-Prado, M.; J.O. Fernandes; A.M. Bello; G. Machado; A.J. Santos; F.Z. Vaz-de-Mello \& A.V.L. Freitas. 2009. Selecting terrestrial arthropods as indicators of small-scale disturbance: A first approach in the Brazilian Atlantic Forest. Biological Conservation 142 (6): 1220-1228. doi: 10.1016/j.biocon. 2009.01.008.

van Name, W.G. 1940. A supplement to the American land and freshwater isopod crustacea. Bulletin of the American Museum of Natural History 77: 109-142.

Vilisics, F.; Z. EleK; G. L. LÖVei; E. Hornug. 2007. Composition of terrestrial isopod assemblages along an urbanisation gradient in Denmark. Pedobiologia 51 (1): 45-53. doi:10.1016/ j.pedobi.2006.12.004.

WerRen, J.H. 1997. Biology of Wolbachia. Annual Review of Entomology 42: 587-609. doi: 10.1146/annurev.ento.42.1.587. 
Willett, T.R. 2001. Spiders and the other arthropods as indicators in old-growth versus logged redwood stands. Restoration Ecology 9 (4): 410-420. doi: 10.1046/j.1526100X.2001.94010.x.

Williams, K.S. 1993. Use of Terrestrial Arthropods to Evaluate Restored Riparian Woodlands. Restoration Ecology 1 (2): 107-116. doi: 10.1111/j.1526-100X.1993.tb00016.x.

Wilson, E.O. 1987. The little things that run the world (The Importance and Conservation of Invertebrates). Conservation Biology 1 (4): 344-346.

Zimmer, M. 2002a. Is decomposition of woodland leaf litter influenced by its species richness? Soil Biology \& Biochemistry 34 (2): 277-284. doi: 10.1016/S0038-0717(01) 00173-0.

Zimmer, M. 2002b. Nutrition in terrestrial isopods (Isopoda:
Oniscidea): an evolutionary-ecological approach. Biological Reviews 77 (4): 455-493. doi: 10.1017/S1464793102005912. Zimmer, M. 2004. Effects of temperature and precipitation on flood plain isopod community: a field study. European Journal of Soil Biology 40 (3-4): 139-146. doi: 10.1016/ j.ejsobi.2005.02.001.

Zimmer, M. \& W. Topp. 1999. Relationships between woodlice (Isopoda: Oniscidea) and microbial density and activity in the field. Biology and Fertility of Soils 30 (1-2): 117-123. doi: $10.1007 / \mathrm{s} 003740050597$.

Zimmer, M.; S.C. Pennings; T.L. Buck \& T.H. Carefoot. 2002. Species-specific patterns of litter processing by terrestrial isopods (Isopoda: Oniscidea) in high intertidal salt marshes and coastal forests. Functional Ecology 16: 596-607. doi: 10.1046/j.1365-2435.2002.00669.x.

Submitted: 26.XII.2009; Accepted: 30.XII.2010.

Editorial responsibility: Heraldo L. de Vasconcelos 